\title{
Characteristics of a Ceramic Carrier after Wastewater Treatment Process in the Model Column Cascade with Ethanol Addition
}

\author{
Andrejs Berzins ${ }^{1, *}$, Zaiga Petrina ${ }^{2}$, Vizma Nikolajeva $^{2}$, Ruta Svinka $^{3}$, Visvaldis Svinka ${ }^{3}$, \\ Silvija Strikauska ${ }^{4}$ and Olga Muter ${ }^{1}$
}

\author{
${ }^{1}$ Institute of Microbiology and Biotechnology, University of Latvia, 4 Kronvalda Blvd., Riga LV-1010, Latvia \\ ${ }^{2}$ University of Latvia, Faculty of Biology, 4 Kronvalda Blvd., Riga, LV-1010, Latvia \\ ${ }^{3}$ Riga Technical University, Faculty of Material Science and Applied Chemistry, Institute of Silicate Materials, 14/24 \\ Azenes Str., Riga LV-1048, Latvia \\ ${ }^{4}$ Latvia University of Agriculture, 2 Liela Str., Jelgava, LV-3001, Latvia
}

\begin{abstract}
Nitrogen and phosphorus removal from wastewater remains one of the serious environmental problems worldwide. The present study was aimed at combining the both nitrification and phosphorus accumulation processes in the laboratory-scale model system. Synthetic wastewaters $\left(28 \mathrm{mg} \mathrm{N}-\mathrm{NH}_{4}{ }^{+} \mathrm{L}^{-1}\right)$ were treated consequently in the cascade of three columns, which were designed for nitrification and phosphorus accumulation processes, respectively, and were packed with porous ceramic beads. Six treatment cycles of seven days in each column were performed. Addition of $3 \%$ ethanol to wastewater increased the efficiency of ammonium removal in the first column of the cascade during the 7 day period to $81.9 \%$, which was accompanied by a decrease of $\mathrm{pH}$ from 7.3 to 6.2 . An increase of soluble phosphates was shown in Columns II and III of the cascade. Microbial enzyme activity, number of CFU and diversity of the microbial community differed among the three columns tested. The most active biofilm formation was detected in Column I. The thermal analysis of beads has revealed mass losses of $0.23 \%$ and $0.08 \%$, due to decomposition of light volatile organic substances at $173{ }^{\circ} \mathrm{C}$ and $481{ }^{\circ} \mathrm{C}$, respectively. In turn, the beads in Column II and III were not covered by thick biofilm, while blue crystals were found on the surface. Accumulation of nitrogen and phosphorus on the beads was detected. Vegetation experiments have revealed some stimulation effect of the beads applied as an amendment to loamy sand soil, to the growth of rye and cress.
\end{abstract}

Keywords: Columns cascade, nitrification, phosphorus accumulation, porous ceramics, synthetic wastewater.

\section{INTRODUCTION}

Municipal wastewaters contain a significant amount of organic matter (chemical oxygen demand - COD), nitrogen $(\mathrm{N})$ and phosphorus $(\mathrm{P})$, which, when improperly discharged, can lead to adverse environmental impact, toxicity to aquatic organisms, depletion of dissolved oxygen etc. [1-2]. Removal of phosphorus and nitrogen from wastewater depends on the initial $\mathrm{pH}$ values, COD, magnesium, calcium, and potassium, incubation time, temperature, excessive aeration, etc. [1]. All of these factors influence the structure and activity of microbial communities responsible for wastewater treatment process.

Another important factor affecting biomass maintenance is an appropriate carrier for cell immobilization. The characteristics of the filter media have a great impact on the treatment efficiency and, to a great extent, determine

*Address correspondence to these authors at the Institute of Microbiology and Biotechnology, University of Latvia, 4 Kronvalda Blvd., Riga LV-1010, Latvia; E-mail: andrejs54@inbox.lv construction and operation costs $[3,4]$. A broad spectrum of technological approaches is used for immobilization of microorganisms, including various organic and inorganic materials. For wastewater treatment, the advantages of an appropriate inert carrier are as follows: insoluble, nonbiodegradable, non-toxic, non-polluting, light weight; flexible in overall shape, highly mechanically and chemically stable, highly diffuse, simple immobilization procedure, high biomass retention, and preferably a low cost [5]. In addition, inert carriers are also much easier to clean and replace [6,7].

Porous ceramic beads have been shown to be an appropriate packing material for wastewater treatment and other biotechnological applications, in particular, due to their high gas and liquid film mass transfer coefficients, high chemical and temperature resistance, mechanical strength, minimization of diffusion limitations of nutrients, etc. $[8,9]$. The asymmetric pore size distribution is ideal for immobilization of microorganisms. During colonization they can easily enter the carrier, where they have a large surface to colonize $[10,11]$. Composition of microbial communities 
in immobilized biomass depends on hydraulic retention time and nitrification efficiency, which increases with increasing hydraulic retention time [12].

Besides, an efficiency of wastewater treatment is dependent on bioreactor design. More than one biofilter layer in the same apparatus or separately designed reactors with different processes in each reactor (e.g., aeration level, microbial community structure, bed packing etc.) can sufficiently increase the rate of wastewater treatment process [13-16].

Phosphate removal from wastewater is one of the serious problems worldwide. Several methods are used to remove phosphorus, e.g. via chemical treatment or by utilizing enhanced biological phosphorus removal (EBPR) processes $[1,17]$. However, successful operation sometimes can be limited by further rehydrolysis of polyphosphates with a consequent release of magnesium and phosphate ions into the solution [18]. Recovering phosphate as struvite crystals (magnesium ammonium phosphate hexahydrate, or MAP) before it forms accumulate on wastewater treatment equipment is considered an alternative solution to this problem [1, 19]. Treatment costs of struvite precipitation could be reduced by (a) using low-cost materials; (b) process recycling of struvite and (c) selling recovered struvite as production [20]. Struvite recovery was found to be dependent on $\mathrm{pH}$, aeration rate, reactor types, $\mathrm{Mg} / \mathrm{P}, \mathrm{N} / \mathrm{P}$ and $\mathrm{Ca} / \mathrm{Mg}$ ratio $[21,22]$. Recently was shown that the presence of $\mathrm{K}^{+}, \mathrm{Ca}^{2+}, \mathrm{Na}^{+}$, and $\mathrm{Mg}^{2+}$ had a significantly negative effect on the removal of ammonia-nitrogen. At the same time, the presence of these ions, except for $\mathrm{Na}^{+}$, had a positive influence on the removal of phosphate [23]. Struvite crystals play a positive role in initial granulation and bacterial group distribution in wastewater treatment [24]. When harvested properly, struvite can be used as a slow release fertilizer. This solves a wastewater treatment problem and provides an environmentally sound and renewable nutrient source to the agriculture industry [25].

Our previous experiments showed the advantages of ceramic beads as a carrier for nitrifying bacteria in the submerged biofiltration system [4]. The present study was aimed at combining both nitrification and phosphorus accumulation processes using synthetic wastewaters treated consequently in the cascade of three columns, which were designed for nitrification, denitrification and phosphorus accumulation processes, respectively. The physicochemical stability of a newly designed ceramic carrier, the changes in the concentrations of biogenic elements in synthetic wastewaters, as well as the shift in microbial community structure in the columns in the case of ethanol addition was evaluated.

\section{MATERIALS AND METHODS}

\section{Bioreactor}

The laboratory-scale model system established for this experiment consisted of 3 columns connected as a batch reactor cascade. Each column was $340 \mathrm{~mm}$ high with $\varnothing 75$ $\mathrm{mm}$. The columns were equipped with a perforated plate supporting the packing material. The air pump (AC-1500, Resun, China) was connected to the first column, thus, providing continuous aeration with a mean air flow of 0.8 $0.95 \mathrm{~L} \mathrm{~min}^{-1}$. The columns were packed with porous ceramic beads (in each column $1.2 \mathrm{~L}$ ), which were previously fabricated from Devonian clay at $1200{ }^{\circ} \mathrm{C}$, being previously tested and evaluated as appropriate for biofilm formation [26]. The ceramic beads had an apparent porosity of 17.78 $\%$, a specific surface area of $4.30 \mathrm{~m}^{2} \mathrm{~g}^{-1}$ and average pore diameter determined by mercury porosimetry $0.35 \mu \mathrm{m}$. The ceramic beads were cylindrical in shape, on average $10 \mathrm{~mm}$ x $5 \mathrm{~mm}$ by size, and had bulk density of $1.58 \mathrm{~g} \mathrm{~cm}^{-3}$. Concentration of $\mathrm{C}, \mathrm{S}, \mathrm{K}$ and $\mathrm{Fe}_{2} \mathrm{O}_{3}$ was $0.60 ; 0.046$; 0.40 , and $34.5 \mathrm{~g} \mathrm{~kg}^{-1}$, respectively. Nitrogen and phosphorus were not detected in the beads.

The columns differed by the microbial consortium inoculated, as well as aeration conditions. Column I was provided with aeration, inoculated with the consortium of nitrifyers, i.e. Nitrosomonas, Nitrobacter, and Pseudomonas sp. Columns II and III were inoculated with Pseudomonas fluorescens AM11. Composition of liquid broth for Column I was as follows, $\mathrm{g} \mathrm{L}^{-1}$ : $\left(\mathrm{NH}_{4}\right)_{2} \mathrm{SO}_{4}-2.0 ; \mathrm{K}_{2} \mathrm{HPO}_{4}-1.0$; $\mathrm{NaCl}-2.0 ; \mathrm{FeSO}_{4}-0.4 ; \mathrm{MgSO}_{4} \cdot 7 \mathrm{H}_{2} \mathrm{O}-0.5 ; \mathrm{CaCO}_{3}-5.0$. Composition of liquid broth for Columns II and III was as follows, $\mathrm{g} \mathrm{L}^{-1}: \mathrm{Na}_{2} \mathrm{HPO}_{4} \cdot 12 \mathrm{H}_{2} \mathrm{O}-6.0 ; \mathrm{KH}_{2} \mathrm{PO}_{4}-3.0 ; \mathrm{NaCl}$ - 0.5; $\left(\mathrm{NH}_{4}\right)_{2} \mathrm{SO}_{4}-0.3 ; \mathrm{FeSO}_{4} \cdot 7 \mathrm{H}_{2} \mathrm{O}-0.002 ; \mathrm{Na}_{2} \mathrm{MoO}_{4}$ $2 \mathrm{H}_{2} \mathrm{O}-0.001$; sugar beet molasses (40\% carbohydrates) 5.0; yeast extract - 2.0. In particular, each column was designated for a separate process, i.e. nitrification, denitrification and phosphorus accumulation, respectively. After 10 days incubation of inoculum in liquid broth in the columns, the liquid phase was discharged from the column, the beads were rinsed once with distilled water and afterwards synthetic wastewater was added.

The experiment was realised by treating the synthetic wastewater in the cascade of columns, i.e. wastewater was added to Column I (aerated "nitrification column" with air flow 0.8-0.95 $\mathrm{L} \mathrm{min}^{-1}$ ), followed by "denitrifying and Paccumulating" Columns II and III performed under nonaerated conditions. The first three cycles (i.e., from 1 to 3 ) were performed with wastewaters without ethanol, while the cycles from 4 to 6 - with $3 \%$ ethanol, respectively. One cycle consisted of three consequent incubations in the columns I, II and III for 7 days in each column. Composition of the synthetic wastewater, $\mathrm{g} \mathrm{L}^{-1}: \mathrm{CO}\left(\mathrm{NH}_{2}\right)_{2}-0.06$; $\left(\mathrm{NH}_{4}\right)_{2} \mathrm{SO}_{4}-0.132 ; \mathrm{Na}_{2} \mathrm{HPO}_{4} \times 12 \mathrm{H}_{2} \mathrm{O}-0.716 ; \mathrm{MgSO}_{4} \mathrm{x}$ $7 \mathrm{H}_{2} \mathrm{O}-0.123 ; \mathrm{CH}_{3} \mathrm{COONa}-0.1 ; \mathrm{NaCl}-0.05$; trace element solution $-10 \mathrm{~mL}$ (with the following composition, $\mathrm{g} \mathrm{L}^{-1}$ : $\mathrm{CoCl}_{2} \cdot 6 \mathrm{H}_{2} \mathrm{O}-0.1 ; \mathrm{ZnSO}_{4}-0.1 ; \mathrm{CuCl}_{2} \cdot 2 \mathrm{H}_{2} \mathrm{O}-0.01$; $\left.\mathrm{H}_{3} \mathrm{BO}_{3}-0.01 ; \mathrm{Na}_{2} \mathrm{MoO}_{4}-0.01 ; \mathrm{NiCl}_{2} \cdot 6 \mathrm{H}_{2} \mathrm{O}-0.02\right)$.

After 6 cycles the columns were disassembled and the beads from the upper, middle and lower parts (due to different conditions) of the columns were sampled for physicochemical and microbiological analyses.

\section{Physicochemical Testing of Wastewater and Ceramic Beads}

Phosphorus determination in wastewater was made using colorimetric ascorbic acid technique [12]. Nessler's reagent was used to determine the ammonia nitrogen concentration. Nitrate was detected in the form of nitrite using $\mathrm{Zn}$ powder 
as reducer to nitrite. Nitrites were determined by spectrometric method at $540 \mathrm{~nm}$, using Griess reagent.

Determination of $\mathrm{Fe}$ (III) oxide in the beads before and after wastewater treatment was carried out according to [27]. Mercury porosimetry, used to determine the porosity, pore size distribution and surface area of pellets, was performed with a Quantachrome porosimeter PoreMaster (USA). A thermal analysis of the beads after use in the columns was carried out for the fine powder. For the experiments thermal analyses equipment SETARAM SETSIS Evolution 1750 till temperature $1000{ }^{\circ} \mathrm{C}$ was used. Ash content was determined according to [28], potassium was determined with AAS according to [29], phosphorus was determined according to [30]. Total nitrogen content was determined according to [31] using an automatic system Auto Kjeldahl Unit K-370 ("Büchi", Switzerland). Total carbon and sulphur was measured with an automatic analyzer CS Eltra ("Eltra", Germany). $\mathrm{pH}$ value and was measured in water (1:5) with pH-meter Hanna pH213 ("Hanna Instruments", USA). To visualize the surface of ceramic beads the light microscope Motic DM-1802 (China) was used.

\section{Microbiological Analyses}

A set of serial dilutions was made from liquid samples and $0.1 \mathrm{~mL}$ from the dilutions were plated on or inoculated in the following media: R2A (Becton \& Dickinson, France) for the aerobic bacterial plate count, malt extract agar (MEA, Becton \& Dickinson, France) for the fungal count, and thioglycollate broth (Bio-Rad, France) for the anaerobic bacteria count. The beads were carefully rinsed twice with sterile distilled water. Three grams of granules were scrubbed and ground in a sterile mortar with a pestle in $3 \mathrm{ml}$ of water to recover the bacteria adsorbed on the granules. The number of detached viable microorganisms was analysed in the serial dilutions of the suspension. Plates and tubes were incubated at $20{ }^{\circ} \mathrm{C}$ for seven days. The number of microorganisms was expressed as logarithms of colonyforming units (CFU) per $\mathrm{mL}$ or gram of sample. Based on colony and cell morphology, predominant fungi were isolated from the highest dilutions of samples and purified using a streaking method. Fungi were identified using macroscopic and microscopic appearance and keys [32].

\section{Testing of Microbial Enzyme Activity}

Microbial enzyme activity was tested in a suspension of crushed ceramic beads. Fluorescein diacetate (FDA) hydrolysis activity was measured according to Chen et al. [33], with some modifications. A $50 \mu \mathrm{L}$ sample was added to $750 \mu \mathrm{L}$ of $0.06 \mathrm{M}$ phosphate buffer $\mathrm{pH} 7.6$ which contained $60 \mu \mathrm{g}$ FDA in $30 \mu \mathrm{L}$ acetone. FDA hydrolysis activity was determined after $60 \mathrm{~min}$ incubation at $37{ }^{\circ} \mathrm{C}$, in triplicate. After incubation, an aliquote of acetone was added, the liquid phase was centrifuged at $4000 \mathrm{rpm}$ and optical density was read at $490 \mathrm{~nm}$. Dehydrogenase activity (DHA) was determined by reduction of 2-p-iodo-3-nitrophenyl-5phenyltetrazolium chloride (INT) to iodonitrophenylformazan, in triplicate. $100 \mu \mathrm{L}$ of $(40 \mathrm{mg}$ INT, $1 \mathrm{~mL} 1 \%$ glucose, $20 \mathrm{~mL} 0.25 \mathrm{M}$ TRIS) were added to $50 \mu \mathrm{L}$ sample. The mixture was incubated at $28{ }^{\circ} \mathrm{C}$ for $48 \mathrm{~h}$. Afterwards 500 $\mu \mathrm{L}$ of the extraction solution (ethanol and dimethyl- formamide 1:1) were added, vortexed and after $30 \mathrm{~min}$ centrifuged at $5000 \mathrm{rpm}$. Optical density was measured at $485 \mathrm{~nm}$ [34]. Urease activity was determined after $24 \mathrm{~h}$ incubation at $37{ }^{\circ} \mathrm{C}$, in triplicate. $50 \mu \mathrm{L}$ sample was placed into $750 \mu \mathrm{L} 0.2 \mathrm{M} \mathrm{K}_{2} \mathrm{HPO}_{4} \cdot 3 \mathrm{H}_{2} \mathrm{O} / \mathrm{KH}_{2} \mathrm{PO}_{4}$ buffer $(\mathrm{pH} 7.1$ ) with $0.1 \%$ urea. Reaction was stopped with $100 \mu \mathrm{L} 1 \mathrm{M} \mathrm{KCl}$. Concentration of $\mathrm{N}^{-\mathrm{NH}_{4}}{ }^{+}$ions was determined with Nessler's reagent at $425 \mathrm{~nm}$.

\section{Microbial Community Analysis by Biolog EcoPlate ${ }^{\mathrm{TM}}$}

Catabolic diversity of the microbial community was determined using Biolog EcoPlate ${ }^{\mathrm{TM}}$ (Biolog, Inc., USA). Measurement of substrate metabolism in EcoPlate ${ }^{\mathrm{TM}}$ is based on color formation from tetrazolium dye, a redox indicator. A $1 \mathrm{~mL}$ suspension of crushed ceramic beads with microorganisms was diluted to $100 \mathrm{ml}$ with sterile $0.85 \%$ $\mathrm{NaCl}$, then inoculated into each well and afterwards incubated for $48 \mathrm{~h}$ at $28{ }^{\circ} \mathrm{C}$. The microbial activity in each well was expressed as average well-color development measured at $620 \mathrm{~nm}$, using microplate reader ASYS Expert Plus (Biochrom, UK). Results of Biolog profiles are presented by the Shannon diversity index to assess the changes in culturable microbial community developed at the end of the experiment on the surface of ceramic beads in three columns of the cascade. For estimation of the Shannon diversity index the following equation (1) was used:

$H=-\Sigma \mathrm{p}_{\mathrm{j}} \log 2 \mathrm{p}_{\mathrm{j}}$

where $\mathrm{p}_{\mathrm{j}}=$ relative intensity of individual well [35].

\section{Vegetation Experiment}

The experiment was performed outdoors in $250 \mathrm{~mL}$ pots. Beads from the columns ( $10 \mathrm{~g})$ were added to $140 \mathrm{~g}$ loamy sand soil. Seeds of rye (Secale cereale L.) and cress (Lepidium sativum L.) represented mono- and dicotyledon plants, were sown in triplicate (10 seeds/pot). After 21 days, the biomass of the aboveground part of the plant was dried at $105{ }^{\circ} \mathrm{C}$ during $24 \mathrm{~h}$, afterwards weighted. Changes of biomass were expressed in percentage, taking the plant biomass from non-amended soil as $100 \%$.

\section{Statistical Analysis}

The statistical data analysis was performed with the Single factor ANOVA Excel software for the significance level 0.05 .

\section{RESULTS AND DISCUSSION}

Our previous study showed the appropriateness of Devonian clay granules as a carrier for biofilm formation [26]. The previous experiment with synthetic wastewaters under similar conditions has revealed a decrease of nitrification efficiency in Column I during the $2^{\text {nd }}$ and $3^{\text {rd }}$ cycles, as compared to the $1^{\text {st }}$ cycle [36]. It is probably caused by a shortage of nutrients for maintaining the activity of nitrifying bacteria attached to the carrier. Recently, certain groups of heterotrophic-nitrifying bacteria such as Pseudomonas spp., Alcaligences spp. etc., were reported to have heterotrophic nitrification and aerobic denitrification ability [4, 37-39]. In this experiment two feeding strategies 
were compared, i.e. the first three cycles were performed with wastewaters only, while in the following three cycles wastewaters were amended with $3 \%$ ethanol.

\section{Changes in the Wastewater During Treatment Process}

As shown in Fig. (1), addition of ethanol in the cycle 4 resulted in considerable $\mathrm{pH}$ changes in all three columns. In particular, the $\mathrm{pH}$ value of wastewaters in Column I was decreased from 7.3 to 6.2 during 7 days of treatment (Fig. 1). The following cycles also demonstrated the lower $\mathrm{pH}$ values, as compared to those without ethanol addition. A similar tendency was revealed also for Column II and III (Fig. 1). Apparently, addition of ethanol was followed by increased metabolic activity of microorganisms, which, in turn, increased the concentration of biomass and metabolites. Concentration of ammonium in wastewaters considerably decreased in the "nitrification" Column I in the presence of ethanol, i.e. cycles 4-6 (Fig. 3). Conversely, in the Column III, an increase of ammonium ions in the treated wastewaters was observed (Fig. 2). As reported by [40], the key environmental factors determining whether nitrite will be

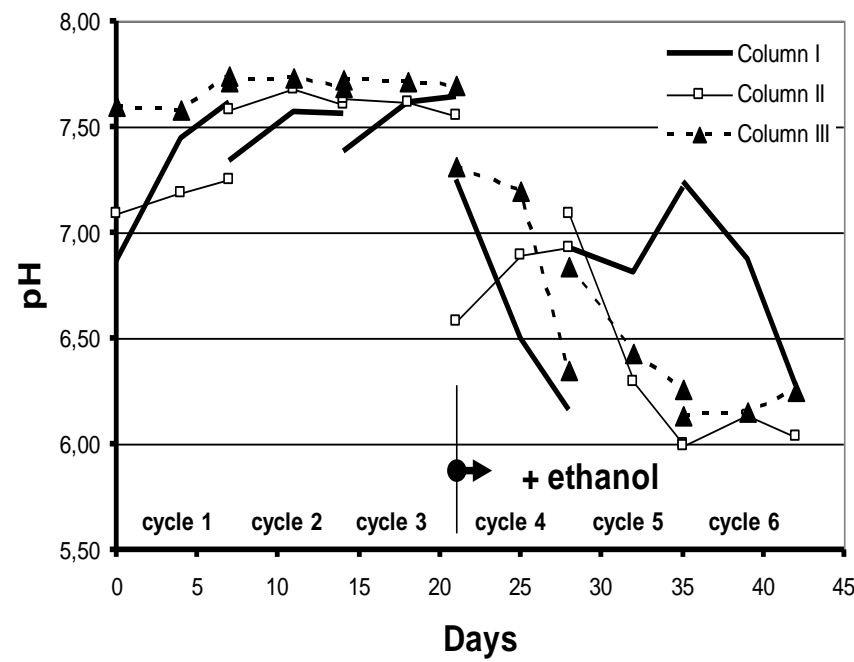

Fig (1). $\mathrm{pH}$ changes of wastewater during six cycles in the column cascade.

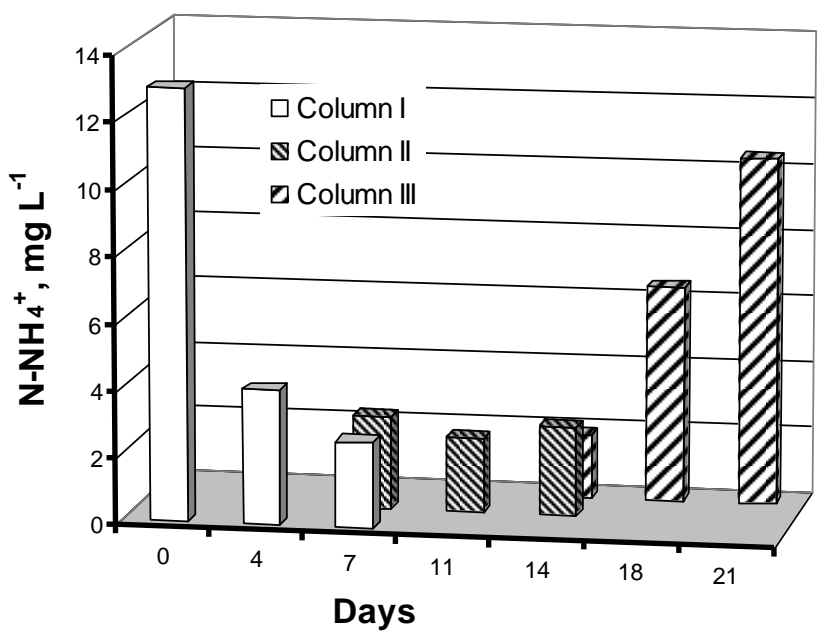

Fig (2). Concentration of ammonium in wastewater during the treatment process in column cascade, cycle 5 . reduced to nitrogenous gas or ammonium, would be microbial generation time, supply of nitrite relative to nitrate, and the carbon/nitrogen ratio. Besides, in case of single anaerobic/aerobic up-flow submerged biofilm reactor the effluent recycling improved ammonia and nitrogen removal, while an enhanced ammonification was shown under aerobic conditions [41]. In our study, an increase of ammonium concentration in Column III could be attributed to specific environmental conditions, which were established during the experiment.

Regarding concentration of phosphates, no considerable changes were detected in Column I and II in the presence of ethanol. Some increase of $\mathrm{P}_{-} \mathrm{PO}_{4}^{3-}$, i.e. from $40.7 \mathrm{mg} \mathrm{L}^{-1}$ to $67.1 \mathrm{mg} \mathrm{L}^{-1}$ was found in Column III in the $4^{\text {th }}$ cycle after 7 days of treatment (Fig. 4). In turn, in the first three cycles without ethanol, there was a notable increase of $\mathrm{P}_{-} \mathrm{PO}_{4}{ }^{3-}$ already in Column II, i.e. from $29.8 \mathrm{mg} \mathrm{L}^{-1}$ to $79.6 \mathrm{mg} \mathrm{L}^{-1}$ (Fig. 4). The increasing of $\mathrm{P}_{-} \mathrm{PO}_{4}{ }^{3-}$ and at the same time the $\mathrm{N}-\mathrm{NH}_{4}{ }^{+}$may indicate that the equilibrium of solubility of low soluble phosphates changes. Some authors show [42] that with decrease of $\mathrm{pH}$ the solubility of phosphate compound (struvite) increases. The increase of phosphates in

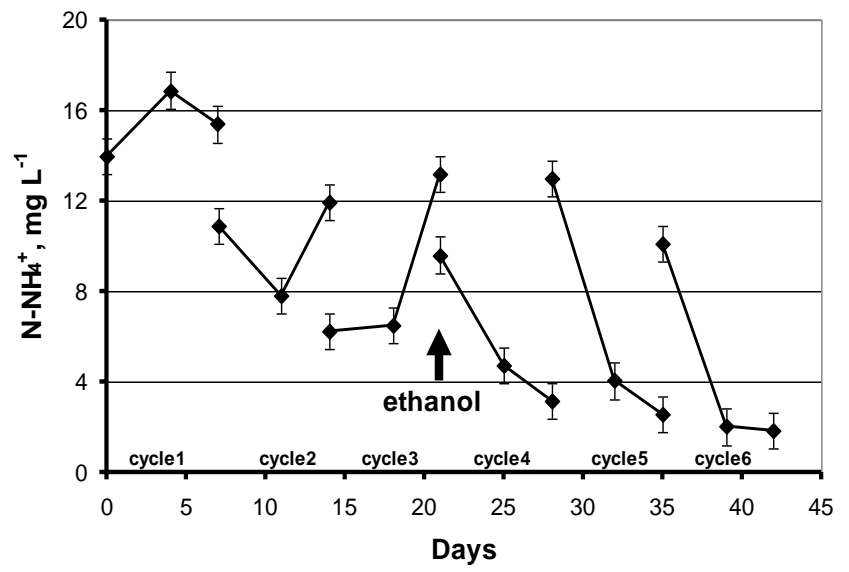

Fig (3). The influence of ethanol addition (cycles 4-6) to wastewater on $\mathrm{NH}_{4}^{+}$concentration in Column I. Initial concentration of $\mathrm{N}^{-\mathrm{NH}_{4}}{ }^{+}$in wastewater was $28 \mathrm{mg} \mathrm{L}^{-1}$.

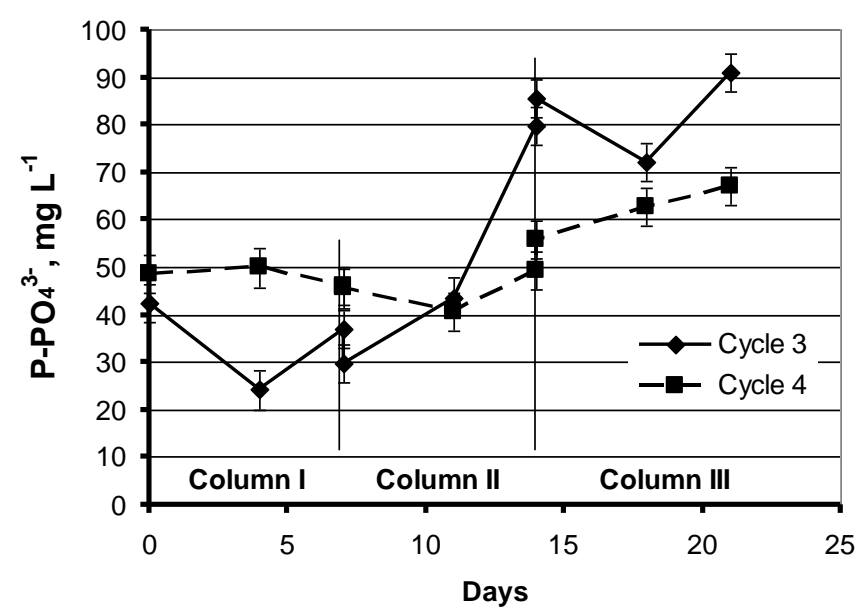

Fig (4). Phosphorus $\left(\mathrm{P}_{-} \mathrm{PO}_{4}{ }^{3-}\right)$ concentration before and after ethanol addition, cycles 3 and 4. Initial concentration of $\mathrm{P}_{-} \mathrm{PO}_{4}{ }^{3-}$ in wastewater was $62 \mathrm{mg} \mathrm{L}^{-1}$. 
the liquid phase (Fig. 4; columns I-III) coincided with the decrease of phosphorus on surface of the beads after the experiment (Table 3).

With regard to nitrification process dynamics, the changes of nitrite and nitrate concentration were compared in cycle 3 and 4, thus, before and after ethanol addition. As shown in Table $\mathbf{1}$, in the presence of ethanol the concentration of $\mathrm{N}-\mathrm{NO}_{2}{ }^{-}$after 7 days of treatment decreased from 1.008 to $0.025 \mathrm{mg} \mathrm{L}^{-1}$. Conversely, some increase of $\mathrm{N}$ $\mathrm{NO}_{3}{ }^{-}$was detected (Table $\mathbf{1}$ ).

Effect of organic compounds on the activity of nitrifying microorganisms depends on the type of organic matter added and the feeding pattern. As reported by Gomez and coworkers [43], ethanol and acetate were consumed in a mixotrophic way by the nitrifying sludge in batch cultures. Moreover, ethanol was found to be an efficient external carbon source also enhancing the denitrification process. The choice of ethanol as the carbon source is considered to be a promising alternative to the more commonly used methanol both with respect to economy and process flexibility [44].

Therefore, an increased activity of biochemical processes detected in the columns with ethanol amendment can be explained by providing additional nutrients for the growth of microbial biomass and as a source of energy. Wastewater treatment performance occurred under non-sterile conditions therefore a specific microbial community was developed in each column. Comparison of three columns of the cascade after cycle 6 has revealed differences in the microbial community and COD in the liquid phase (Table 2). The counts of aerobic bacteria per $\mathrm{ml}$ of wastewater liquid averaged at $8 \log$ CFU in column I and II and at $7 \log$ CFU in column III, anaerobic bacteria at $6 \log \mathrm{CFU}$ in all three columns, filamentous fungi at $6 \log \mathrm{CFU}$ in Column I, from 4 to $5 \log$ CFU in Column II and $4 \log$ in Column III, and yeasts at 5-6 $\log \mathrm{CFU}$ in all three columns. The highest concentration of filamentous fungi and yeasts was detected in the liquid phase of Column I. While the highest CFU number of bacteria was found in Column II, afterwards it was considerably reduced in Column III, i.e., from $95 \mathrm{mln}$ $\mathrm{CFU} \mathrm{mL} \mathrm{m}^{-1}$ to $4.3 \mathrm{mln} \mathrm{CFU} \mathrm{mL}$, respectively (Table 2). Apparently ethanol was consumed by microorganisms mostly in the first stage of the cascade, i.e. Column I. A continuous decrease of COD in the treated wastewaters through the cascade stages can indicate a reduced amount of suspended microbial biomass, thus supporting the statement about a non-equal distribution of the additional carbon source among columns of the cascade. This makes the process more heterogenic in terms of the study on the ethanol influence on the whole process.

\section{Physicochemical and Microbiological Characteristics of the Ceramic Carrier at the End of the Experiment}

A heterogeneity of the processes occurring in the column cascade was predicted by the experiment design, which included different microbial cultures initially inoculated, different composition of liquid broth, aeration conditions, as well as a non-equal consumption of ethanol among the stages of the cascade. As a result, the packing material sampled from three columns at the end of the experiment differed by chemical and microbiological characteristics. A visual comparison of beads has revealed a principal difference between ceramic beads in Column I and the subsequent two columns (Fig. 5). An intensive growth of microorganisms when ethanol was added to wastewaters (cycles 4-6) resulted in formation of a strong biofilm (Fig. 5A). White crystals on the bead surface in Column I were originated from nutrient broth used at the beginning of the experiment for cultivation of nitrifying bacteria (excess of $\mathrm{CaCO}_{3}$ ) (Fig. 5B). In turn, the surface of the packing material sampled from Columns II and III, was not covered by a thick biofilm, while blue crystals were found on the ceramic beads (Fig. 5C, D, E).

Thermal analysis of the beads from Column I showed three characteristic peaks on the thermogram (Fig. 6). In particular, mass losses of $0.23 \%$ and $0.08 \%$ were detected, due to decomposition of organic substances with different

Table 1. Changes of nitrate and nitrite concentration in Column I after 7 days of treatment before and after ethanol addition to wastewater, $\mathrm{mg} \mathrm{L}^{-1}$.

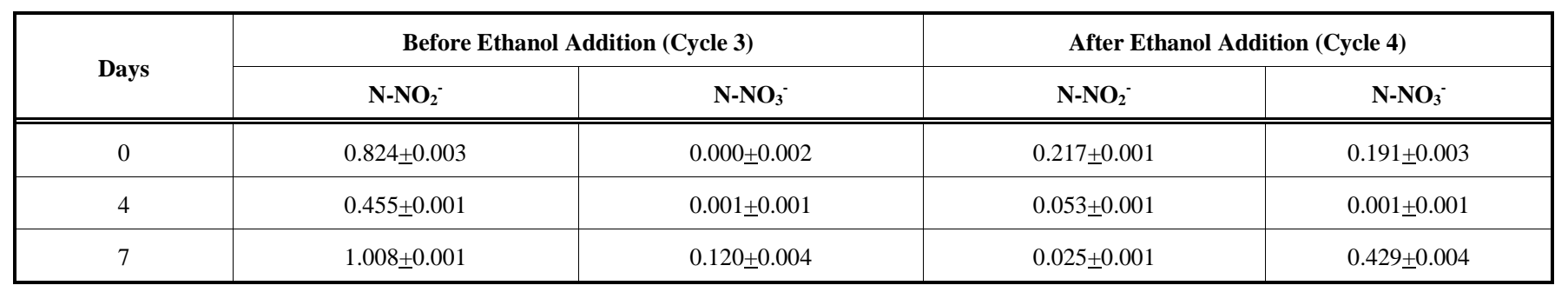

Table 2. Chemical oxygen demand, $\mathrm{mg} \mathrm{L}^{-1}$, and the number of colony-forming units (CFU) $\mathrm{mL}^{-1}$ in the liquid phase from the cascade columns after 7 days of treatment in cycle 6 (initial COD was $1436 \mathrm{mg} \mathrm{L}^{-1}$ ).

\begin{tabular}{|c|c|c|c|c|c|}
\hline Column & COD & Aerobic Bacteria & Filamentous Fungi & Yeasts & Anaerobic Bacteria \\
\hline \hline I & 141 & $7.3 * 10^{7}$ & $5.3 * 10^{5}$ & $8.0 * 10^{5}$ & $1.0 * 10^{6}$ \\
\hline II & 128 & $9.5 * 10^{7}$ & $1.0 * 10^{4}$ & $2.0 * 10^{5}$ & $1.0 * 10^{6}$ \\
\hline III & 83 & $4.3 * 10^{6}$ & $5.0 * 10^{3}$ & $4.3 * 10^{4}$ & $1.0 * 10^{6}$ \\
\hline
\end{tabular}


decomposition temperature at $173{ }^{\circ} \mathrm{C}$ and $481{ }^{\circ} \mathrm{C}$, respectively. In addition, formation of inorganic composition on the surface of pellets, which decomposed during thermal analysis at temperature $682{ }^{\circ} \mathrm{C}$ and characterized with endothermic effect and mass loss $0.10 \%$, was detected. XRay phase analysis indicated that this compound was $\mathrm{CaCO}_{3}$.

Chemical analysis showed the differences in the content of $\mathrm{N}, \mathrm{P}, \mathrm{C}$, and $\mathrm{S}$ in the beads. In particular, $\mathrm{N}, \mathrm{C}$ and $\mathrm{S}$ in the beads were found to increase in Column III, as compared to non-treated beads and Column I. Conversely, the lowest concentration of $\mathrm{P}$ was detected in the final step of the process, i.e. in Column III (Table 3). These data are in a good agreement with those shown for the liquid phase of Column III, where an increase of soluble $\mathrm{P}_{-} \mathrm{PO}_{4}^{-3}$ was shown (Fig. 4). The concentrations of $\mathrm{K}$ and $\mathrm{Fe}_{2} \mathrm{O}_{3}$ in the ceramic beads were not changed during the experiment (Table $\mathbf{3}$ ). The specific surface area of the ceramic beads sampled from Columns I and II, was decreased from $4.30 \mathrm{~m}^{2} \mathrm{~g}^{-1}$ for the control (beads without treatment) to $4.12 \mathrm{~m}^{2} \mathrm{~g}^{-1}$ and $4.07 \mathrm{~m}^{2}$ $\mathrm{g}^{-1}$, respectively (Table 3 ). While ceramic beads from Column III were characterized by the highest specific surface area, as compared to the columns I and II and the control (Table 3).

Comparison of microbial activity on the ceramic bead

Table 3. Physicochemical and microbiological characteristics of the ceramic beads after the experiment.

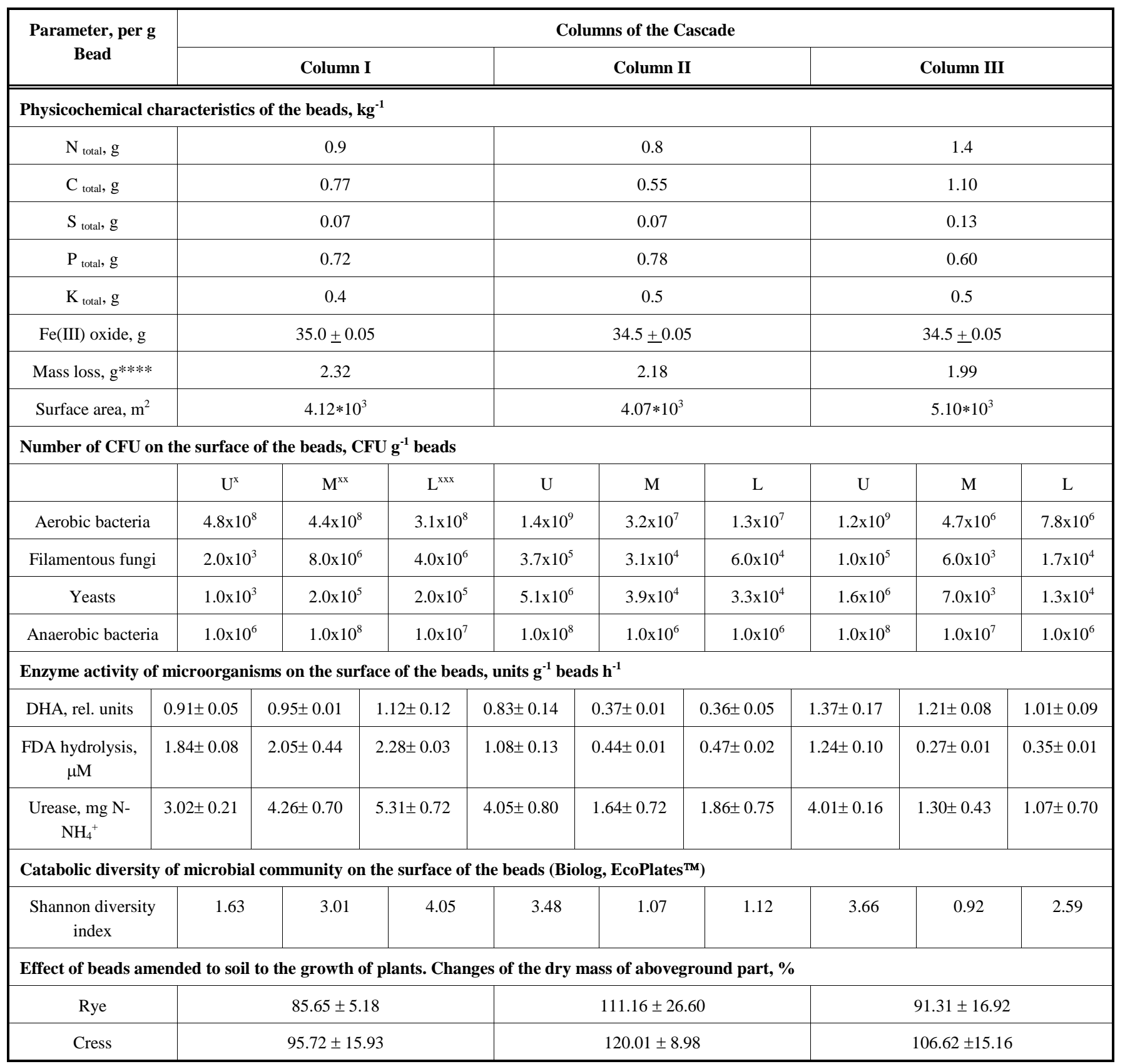

* Upper layer; ** Middle layer; *** Lower layer

**** Mass variations during thermal analysis from $100{ }^{\circ} \mathrm{C}$ to $173{ }^{\circ} \mathrm{C}$

The values are means \pm standard error. $\mathrm{N}=$ for each sampling depth 
surface in the tested columns revealed differences of microbial enzyme activity, number of CFU and diversity of microbial community among the three columns tested. Moreover, microbial activity differed at different column heights. In particular, the highest FDA hydrolysis activity was detected on the lower level in Column I. FDA activity of immobilized microorganisms in Columns II and III was dramatically decreased, with the lowest activity in the middle and lower levels. The differences of DHA activity in the tested columns at the end of the experiment were similar to those shown for FDA hydrolysis activity (Table 3). The highest DHA activity was revealed for microorganisms in Column III, while the lowest - in Column II, respectively.
For both FDA hydrolysis and DHA activity, a common relationship of enhancing enzyme activity directed to the upper layer, was shown for both Column II and III. This fact can be explained by more intensive aeration due to passive air diffusion. Conversely, Column I was continuously aerated by up-flow air pumping, therefore, the bottom level of the column was the most saturated with oxygen. The changes in enzyme activity of microorganisms immobilized on the ceramic carrier dependent on the cascade step and column level (depth) was shown also for urease (Table 3 ).

The count of aerobic bacteria per gram of moist ceramic carrier averaged at 7-9 $\log \mathrm{CFU}$, from 6 to $8 \log \mathrm{CFU}$ of the
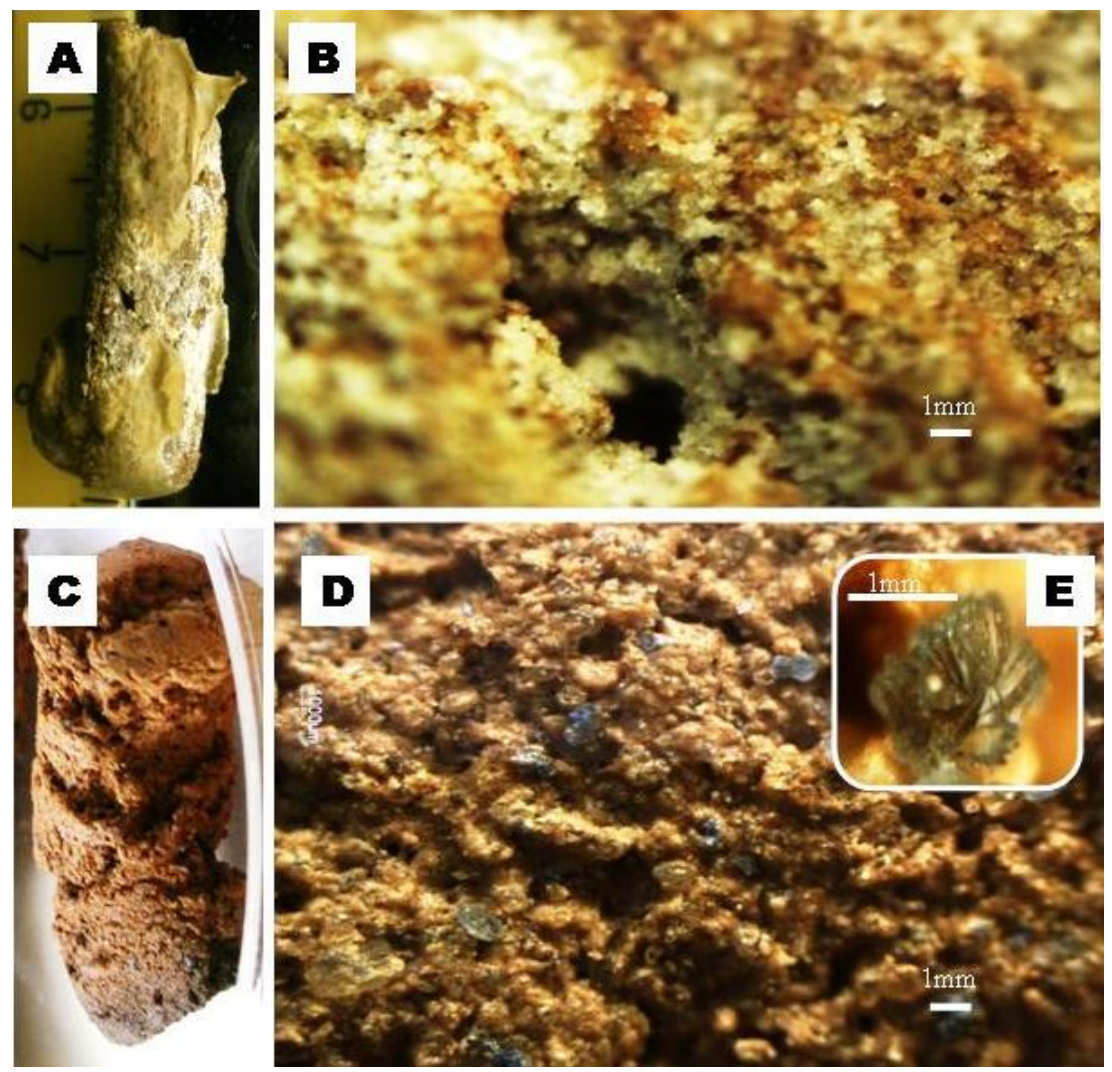

Fig (5). Micrographs of the surface of ceramic beads sampled from Column I (A, B) and Column III $(\mathbf{C}, \mathbf{D}, \mathbf{E})$ at the end of the experiment. Formation of crystals on the beads in Column I was caused by excess of $\mathrm{CaCO}_{3}$ in liquid broth, which was applied at the initial stage of the experiment when consortium of nitrifyers was inoculated. Blue crystals on the beads in Column III were formed during wastewater treatment.

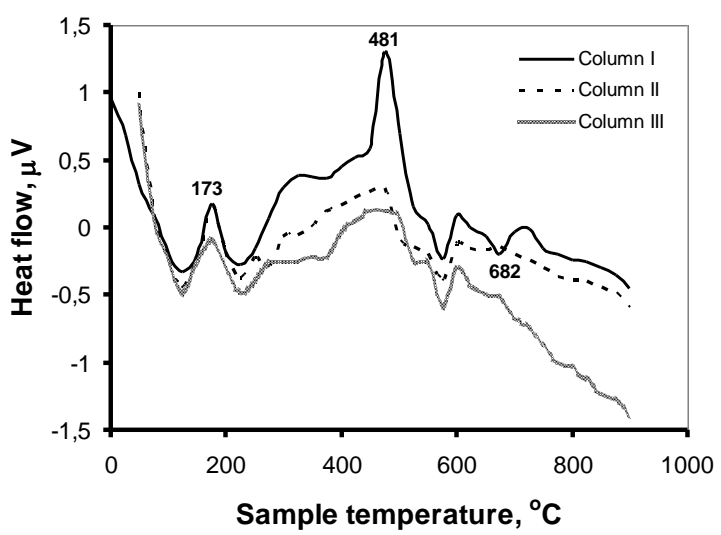

Fig (6). Thermograms of ceramic beads sampled from Columns I, II and III at the end of the experiment. 
anaerobic bacteria, as well as from 4 to $7 \log \mathrm{CFU}$ of the filamentous fungi and from 3 to $7 \log \mathrm{CFU}$ of yeasts (Table 3). Filamentous fungus Fusarium sp. and pink coloured yeast Rhodotorula sp. were found to be predominant in all of the analysed samples of the liquid phase as well as on the ceramic carriers.

The heterogeneity of microbial activity in the three columns as well as along the column height can be caused by different physicochemical conditions and, therefore, different intensity of biofilm formation. In addition, different conditions during the experiment can sufficiently influence the diversity of microbial community on the carrier. Indeed, comparison of the Shannon's diversity index obtained on EcoPlate $^{\mathrm{TM}}$ for three different levels of the three columns indicated the changes in the structure of the microbial community with a similar tendency as was shown for microbial enzyme activity (Table 3). The major factors shaping microbial communities were reported to be such environmental variables as: hydraulic retention time, influent $\mathrm{COD}, \mathrm{NH}_{4}{ }^{+}-\mathrm{N}$, temperature, etc. mixed liquid temperature and humic substances [45].

Characteristics of ceramic beads after the experiment showed the nitrogen and phopshorous concentrating on concentration of nitrogen and phosphorus on their surface, as well as proliferation of different microorganisms, which could produce either an inhibition or stimulation effect on the growth of plants. In case the used ceramic beads after wastewater treatment will be utilized as an alternative fertilizer, it would be important to test them in vegetation experiments. Comparison of rye and cress response to the presence of the used ceramic beads in loamy sand soil showed the plant species specific effect after a 21-day vegetation experiment. The highest increase of dry mass of aboveground biomass (11\% - 20\% higher than in the control) was detected for all three species in soil amended with beads from Column II. Beads from Columns I and III under test conditions inhibited the growth of rye (Table $\mathbf{3}$ ).

Massey and coworkers reported the results of a greenhouse study with spring wheat, using triple superphosphate, organic rock phosphate, recovered struvite, dittmarite, and a heterogeneous recovered phosphate as a fertilizer. All fertilizers generally performed similarly to one another, increasing plant dry matter over control [46].

Summarizing the results obtained in this study, it can be concluded that the model system constructed in this study has a potential for further development of the wastewater treatment process in the columns cascade. The porous ceramic beads were shown to be a stable supporting material for microbial immobilization. The ethanol addition stimulated ammonia removal from synthetic wastewater. Concentration of $\mathrm{N}$ and $\mathrm{P}$ on the bead surface during the process was detected. Some increase of soluble phosphates was shown in Columns II and III of the cascade. Apparently this effect was caused by rehydrolysis of polyphosphates from biomass and decrease of $\mathrm{pH}$. The scheme of further experiments can be modified by shortening the retention time of wastewater in the columns as well as optimizing the "beads : liquid phase" ratio.

\section{CONFLICT OF INTEREST}

The authors confirm that no conflicts of interest are associated with this article.

\section{ACKNOWLEDGEMENTS}

The study was financed by National Research Programme of Latvia [Programme No. 2010.10-4/VPP-5 "Sustainable Use of Local Resources (Mineral Deposits, Forests, Food and Transport) - New Products and Technologies" and Programme ResProd].

\section{REFERENCES}

[1] de-Bashan LE, Bashan Y. Recent advances in removing phosphorus from wastewater and its future use as fertilizer. Water Res 2004; 38:4222-46.

[2] Pramanik B, Fatihah S, Shahrom Z, Ahmed E. Biological aerated filters (BAFS) for carbon and nitrogen removal: a review. J Eng Sci Tech 2012; 7: 428-46.

[3] Han S, Yue Q, Yue M, et al. Effect of sludge-fly ash ceramic particles (SFCP) on synthetic wastewater treatment in an A/O combined biological aerated filter. Biores Technol 2009; 100: 1149-55.

[4] Muter O, Mihailova A, Berzins A, et al. Optimization of nitrification process by a bacterial consortium in the submerged biofiltration system with ceramic bead carrier. J Microb Biochem Technol 2014; 6: 148-53. doi:10.4172/1948-5948.1000136

[5] Martins SCS, Martins CM, Fiúza LMCG, Santaella ST. Immobilization of microbial cells: a promising tool for treatment of toxic pollutants in industrial wastewater. Afr J Biotech 2013; 12 4412-8.

[6] Janiszyn Z, Dziuba E, Boruczkowski T, et al. Application of porous ceramic sinter as a support for immobilization of Saccharomyces cerevisiae yeast cells. Pol J Food Nutr Sci 2007; 57: 251-5.

[7] Hirai M, Kamamoto M, Yani M, Shoda M. Comparison of the biological NH3 removal characteristics among four inorganic packing materials. J Biosci Bioeng 2001; 91: 428-30.

[8] Nikolajeva V, Griba T, Petrina Z. Factors influencing adhesion of Pseudomonas putida on porous clay ceramic granules. Env Exp Biol 2012; 10: 77-80.

[9] Phosphorous determination using the colorimetric ascorbic acid technique. CEE 453: Laboratory Research in Environmental Engineering, Cornell University, Ithaca, Spring 2001, pp. 64-9

[10] Wojnowska-Baryła I, Zielińska M. Carbon and nitrogen removal by biomass immobilized in ceramic carriers. Pol J Environ Stud 2002; 11: 577-84.

[11] Kakariminiaae-Hamedaani HR, Kanda K, Kato F. Wastewater treatment with bacteria immobilized onto a ceramic carrier in an aerated system. J Biosci Bioeng 2003; 95: 128-32.

[12] Zielinska M, Cydzik-Kwiatkowska A, Wojnowska-Baryla I. Changes in microbial communities of nitrifying immobilized biomass: the role of operational conditions. Pol J Environ Stud 2012; 21: 1107-12

[13] Osorio F, Hontoria E. Wastewater treatment with a double-layer submerged biological aerated filter, using waste materials as biofilm support. J Env Manag 2002; 65: 79-84.

[14] Luo W, Yang C, He H, et al. Novel two-stage vertical flow biofilter system for efficient treatment of decentralized domestic wastewater. Ecol Eng 2014; 64: 415-23.

[15] Wu Y, Hu Z, Kerr PG, Yang L. A multi-level bioreactor to remove organic matter and metals, together with its associated bacterial diversity. Biores Technol 2011; 102: 736-41.

[16] Ong S, Lee L, Hu J, Ng W. Nitrogen removal using combined ultracompact biofilm reactor - packed bed system. J Env Eng 2003; 129 (1): 43-51.

[17] Duenas JF, Alonso JR, Rey AF, Ferrer AS. Characterisation of phosphorous forms in wastewater treatment plants. J Hazard Mater 2003; 97: 1-3. 
[18] Jardin N, Popel JJ. Behaviour of waste activated sludge from enhanced biological phosphorus removal during sludge treatment. Water Environ Res 1996; 68: 965-73.

[19] Adnan A, Mavinic DS, Koch FA. Pilot-scale study of phosphorus recovery through struvite crystallization - examining the process feasibility. J Environ Eng Sci 2003; 2: 315-24.

[20] Huang H, Song Q, Zhao X, et al. Reduction in the cost for ammonia removal by struvite precipitation technology. Sila Sci2012, 29(1): 289-98.

[21] Guadie A, Xia S, Jiang W, et al. Enhanced struvite recovery from wastewater using a novel cone-inserted fluidized bed reactor. J Environ Sci (China) 2014, 26(4): 765-74.

[22] Rahman MM, Salleh MAM, Rashid U, et al. Production of slow release crystal fertilizer from wastewaters through struvite crystallization - a review. Arab J Chem 2014, 7(1): 139-55.

[23] Huang H, Xiao D, Pang R, et al. Simultaneous removal of nutrients from simulated swine wastewater by adsorption of modified zeolite combined with struvite crystallization. Chem Eng J 2014, 256(15): 431-8.

[24] Wang G, Wang D, Xu X, et al. Partial nitrifying granule stimulated by struvite carrier in treating pharmaceutical wastewater. Appl Microbiol Biotechnol 2013, 97(19): 8757-65.

[25] Munch E, Barr K. Controlled struvite crystallization for removing phosphorus from anaerobic digester sidestreams. Water Res 2001; 35: 151-9.

[26] Muter O, Potapova K, Nikolajeva V, et al. Comparative study on bacteria colonization onto ceramic beads originated from two Devonian clay deposits in Latvia. Sci J RTU: Mat Sci Appl Chem 2012; 26: 134-9.

[27] LVS EN 196-2:2013. Method of testing cement - Part 2: Chemical analysis of cement. 31.10.2013.

[28] ISO 5984:2002/Cor 1:2005. Animal feeding stuffs. Determination of crude ash. 2005.

[29] LVS EN ISO 6869:2002 Animal feeding stuffs. Determination of the contents of calcium, copper, iron, magnesium, manganese, potassium, sodium and zinc. Method using atomic absorption spectrometry. 2002.

[30] ISO 6491:1998. Animal feeding stuffs. Determination of phosphorus content. Spectrometric method. 1998.

[31] ISO 5983-2:2009. Animal feeding stuffs. Determination of nitrogen content and calculation of crude protein content. Part 2: Block digestion and steam distillation method.2009.

[32] Kiffer E, Morelet M. the deuteromycetes - mitosporic fungi: classification and generic keys. Enfield, USA: Science Publishers, 2000: p. 273.
[33] Chen W, Hoitink H, Schmitthenner A, Tuovinen O. The role of microbial activity in suppression of damping-off caused by Pythium ultimum. Phytopathol 1988; 78: 314-22.

[34] Camiña F, Trasar-Cepeda C, Gil-Sotres F, Leirós C. Measurement of dehydrogenase activity in acid soils rich in organic matter. Soil Biol Biochem 1998; 30: 1005-11.

[35] Gabor EM, de Vries EJ, Janssen DB. Efficient recovery of environmental DNA for expression cloning by indirect extraction methods. FEMS Microbiol Ecol 2003; 44: 153-63.

[36] Vecstaudža D, Bērzin̦s A, Mutere O, et al. Fosfora un slāpekḷa savienojumu noārdīšana sintētiskos notekūdenos keramikas granulu biofiltrā. (Degradation of phosphorus and nitrogen in synthetic wastewaters using ceramic beads-packed biofilter). Book of Abstract. $72^{\text {th }}$ Conference of the University of Latvia. Geography, Geology, Environment 2014, 337-8 (In Latvian).

[37] Zhang J, Wu P, Hao B, Yu Z. Heterotrophic nitrification and aerobic denitrification by the bacterium Pseudomonas stutzeri YZN-001. Biores Technol 2011; 102: 9866-9.

[38] Joo HS, Hirai M, Shoda M. Characteristics of ammonium removal by heterotrophic nitrification-aerobic denitrification by Alcaligenes faecalis. J Biosci Bioeng 2005, 100 (2): 184-91.

[39] Ding W, Zhu L, Xu J, et al. Progress of researches on aerobic denitrifiers and their application in bioremediation. Chin J Appl Environ Biol 2011, 17(6): 923-9.

[40] Kraft B, Tegetmeyer HE, Sharma R, et al. The environmental controls that govern the end product of bacterial nitrate respiration. Science 2014, 345 (6197): 676-9.

[41] El-Shafai SA, Zahid WM. Performance of aerated submerged biofilm reactor packed with local scoria for carbon and nitrogen removal from municipal wastewater. Biores Technol 2013, 143: 476-82.

[42] Babic-Ivancic V, Kontrec J, Kralj D, Brecevic L. Precipitation diagrams of struvite and dissolution kinetics of different struvite morphologies. Croatica Chem Acta 2002; 75: 89-106.

[43] Gomez J. Mendez R. Lema JM. Kinetic study of addition of volatile organic compounds to a nitrifying sludge. Appl Biochem Biotechnol 2000; 87: 189-202.

[44] Peng Y-Z, Ma Y, Wang S-Y. Denitrification potential enhancement by addition of external carbon sources in a pre-denitrification process. J Environ Sci 2007; 19: 284-9.

[45] Sun Y, Shen Y-X, Liang P, et al. Linkages between microbial functional potential and wastewater constituents in large-scale membrane bioreactors for municipal wastewater treatment. Wat Res 2014: 56: 162-71.

[46] Massey MS, Davis JG, Ippolito JA, Sheffield RE. Effectiveness of recovered magnesium phosphates as fertilizers in neutral and slightly alkaline soils. Agron J 2009, 101(2): 323-9.

Received: November 20, 2014

Revised: February 23, 2015

Accepted: January 03, 2015

(c) Berzins et al.; Licensee Bentham Open.

This is an open access article licensed under the terms of the Creative Commons Attribution Non-Commercial License (http://creativecommons.org/licenses/by-nc/3.0/) which permits unrestricted, non-commercial use, distribution and reproduction in any medium, provided the work is properly cited. 